\title{
Numerical Study of Compact Plate-Fin Heat Exchanger for Rotary-Vane Gas Refrigeration Machine
}

\section{V. Trandafilov ${ }^{\bowtie}$, M. G. Khmelniuk}

Odessa National Academy of Food Technologies, 112 Kanatnaya str., Odessa, 65039, Ukraine

$₫$ e-mail: vlad.trandafilov@gmail.com, ORCID: https://orcid.org/0000-0001-9905-9958

\begin{abstract}
Plate-fin heat exchangers are widely used in refrigeration technique. They are popular because of their compactness and excellent heat transfer performance. Here we present a numerical model for the development, research and optimization of a plate-fin heat exchanger for a rotary-vane gas refrigeration machine. The method of analysis by graphic method of plate - fin heat exchanger is proposed. The model describes the effects of secondary parameters such as axial thermal conductivity through a metal matrix of the heat exchanger. The influence of geometric parameters and heat transfer coefficient is studied. Graphs of dependences of length, efficiency of a fin and pressure drop in a heat exchanger on the thickness of the fin and the number of fins per meter are obtained. To analyze the results of numerical simulation, the heat exchanger was designed in the Aspen HYSYS program. The simulation results show that the total deviation from the proposed numerical model is not more than $15 \%$.
\end{abstract}

Keywords: Rotary-vane gas refrigerating machine; Plate-fin heat exchanger; Numerical model; Helium

\section{Чисельне дослідження компактного пластинчато-ребристого теплоо- бмінника для роторно-лопатевої газової холодильної машини}

\author{
В. В. Трандафілов, М. Г. Хмельнюк
}

Одеська національна академія харчових технологій, вул. Канатна, 112, Одеса, 65039, Україна

\begin{abstract}
Пластинчато-ребристі теплообмінники широко використовуються в холодильній техніці. Вони популярні завдяки їх компактності та чудовій теплопередачі. У статті представлено чисельну модель для розробки, дослідження і оптимізації пластинчато-ребристого теплообмінника для роторно-лопатевій газової холодильної машини. Запропоновано методику аналізу графічним методом пластинчато - ребристого теплообмінника. Модель описує ефекти вторинних параметрів, таких як аксіальна теплопровідність через металеву матрицю теплообмінника. Вивчено вплив геометричних параметрів та коефіцієнта теплопередачі. Отримано графіки залежностей довжини, ефективності ребра та падіння тиску в теплообміннику від товщини ребра та кількості ребер на метр. Для аналізу результатів чисельного моделювання теплообмінник був спроектований в програмі Aspen HYSYS. Результати моделювання показують, щчо загальне відхилення від запропонованої чисельної моделі становить не більше ніж $15 \%$.
\end{abstract}

Ключові слова: Роторно-лопатева газова холодильна машина; Пластинчато-ребристий теплообмінник; Чисельна модель; Гелій

DOI: http://dx.doi.org/10.15673/ret.v53i2.589

(C) The Author(s) 2017. This article is an open access publication

This work is licensed under the Creative Commons Attribution 4.0 International License (CC BY) http://creativecommons.org/licenses/by/4.0/

\section{Introduction}

Plate-fin heat exchangers (PFHE) having very high effectiveness $(>0.95)$ are employed in modern helium refrigeration systems. These devices are constructively performed counter-current, cross-flow and straight-through. In terms of mass-size and performance indicators, these devices are considered effective compact heat exchangers. The compactness of the surface in them is $1000-3000 \mathrm{~m}^{2} / \mathrm{M}^{3}$.
There are surfaces, compactness of which reaches 6000 $\mathrm{m}^{2} / \mathrm{m}^{3}[1]$.

The major applications of PFHE demand them to possess the properties of high thermal conductivity so as to enable high heat transfer [2]. Further, the material needs to retain its strength and ductility even at low temperatures. Therefore, amongst all the materials, aluminum alloys (Al 3003 and $\mathrm{Al} \mathrm{6061)}$ were found to be most suitable for the construction of heat exchanger. In the current design, 


\begin{tabular}{|ll|ll|}
\hline \multicolumn{4}{|c|}{ Nomenclature } \\
\hline $\mathrm{L}$ & length $(\mathrm{m})$ & $\mathrm{h}$ & heat transfer coefficient $\left(\mathrm{W} / \mathrm{m}^{2} \mathrm{~K}\right)$ \\
$\mathrm{H}$ & height $(\mathrm{m})$ & $\mathrm{A}_{\mathrm{ff}}$ & Free flow area $\left(\mathrm{m}^{2}\right)$ \\
$\mathrm{W}$ & width $(\mathrm{m})$ & $\Delta \mathrm{P}$ & pressure drop $(\mathrm{Pa})$ \\
$\mathrm{t}_{\mathrm{f}}$ & fin thickness $(\mathrm{m})$ & $\mathrm{j}$ & Colburn factor \\
$\mathrm{h}$ & fin height $(\mathrm{m})$ & $\rho$ & density $\left(\mathrm{kg} / \mathrm{m}^{3}\right)$ \\
$c_{p}$ & gas specific heat for constant pres- & $\mathrm{m}$ & mass $(\mathrm{kg})$ \\
$\mathrm{T}$ & sure $(\mathrm{kJ} / \mathrm{kgK})$ & $\eta_{\mathrm{f}}$ & fin efficiency $(\%)$ \\
$\mathrm{Q}$ & temperature $(\mathrm{K})$ & $\mathrm{f}$ & friction factor \\
\hline
\end{tabular}

Al 3003 was selected as the base material on account of its low cost and high manufacturing ability.

Therefore, the design of compact and high-effectiveness PFHE requires careful consideration of axial heat conduction. In addition, working fluid properties and metal conductivity change considerably with temperature and can lead to significant errors in models that assume constant properties. Herein, we present a numerical model that explicitly accounts for the effect of axial conduction and variable properties and discuss the initial results. Illustration of PFHE is shown on figure 1.
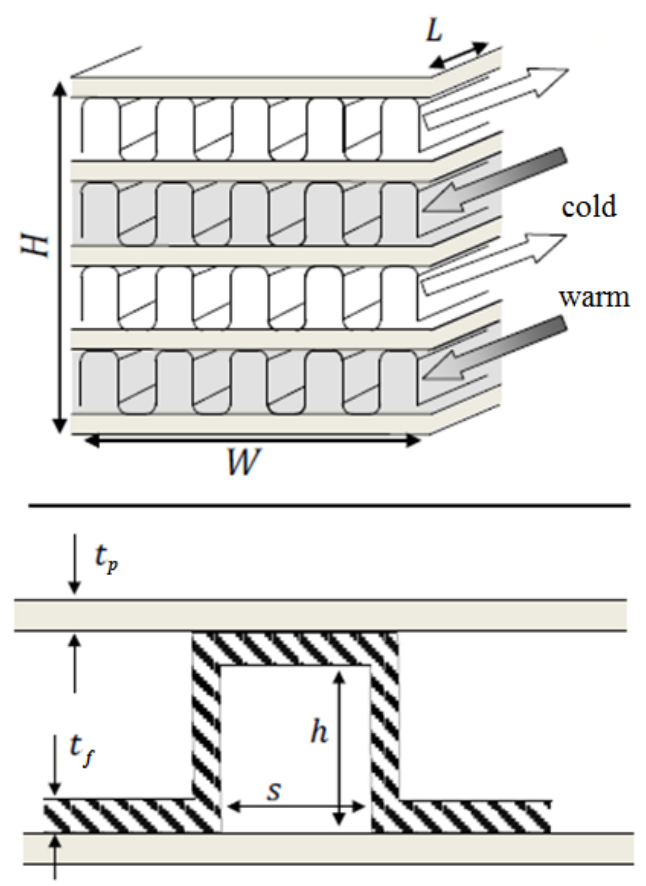

Figure 1 - Illustration of PFHE

\section{Numerical heat exchanger model}

The Reynolds number $(R e)$ is a measure of flow characteristic of heat exchanger. It is directly proportional to the flow momentum rate and inversely proportional to the viscous force for a specified geometry:

$$
\operatorname{Re}=\frac{G \cdot D_{h}}{\mu}
$$

$$
G=\frac{m}{A_{f f}}
$$

The value of Re is different for all the streams. For the value of $G$ in case of all the streams are, $G_{h l}, G_{h 2}, G_{c}$ for hot 1 , hot 2 and cold stream respectively for different mass flow rates and different values of free flow area such as $A_{f f l}$, $A_{f f 2}, A_{f f c}$ respectively.

By employing continuous expressions of Fanning friction factor $f$ and Colburn factor $j$, which are functions of Reynolds number and basic fin geometry parameters. For $120<\operatorname{Re}<10^{4}$ :

$$
\begin{aligned}
& j=0.233 \cdot R e^{-0.48}\left(\frac{s}{b}\right)^{0.192}\left(\frac{t_{f}}{b}\right)^{-0.208} \\
& f=0.029 \cdot R e^{-0.09}\left(\frac{s}{b}\right)^{0.034}\left(\frac{t_{f}}{b}\right)^{-0.169}
\end{aligned}
$$

The optimum compact heat exchanger is a trade-off between selecting surfaces with higher $j$ factors (to

minimize required heat transfer area) and selecting surfaces with lower $f / j$ ratios to achieve better heat transfer for the permitted pressure drop. What is considered 'optimum' is driven by end-user requirements, some examples being minimal cost, weight, installed height, or footprint.

The heat transfer coefficient and pressure drop are:

$$
\begin{gathered}
h=j \cdot G \cdot c_{p} \cdot \operatorname{Pr}^{-2 / 3} \\
\Delta P=\frac{2 f L G^{2}}{\rho D_{h}}
\end{gathered}
$$

The length $L$ can be determined by:

$$
L=\frac{Q}{U A \cdot L M T D}
$$

Where, log mean temperature difference (LMTD) can be calculated by:

$$
L M T D=\frac{\left(T_{h 1-i}-T_{c o}\right)-\left(T_{h 1-o}-T_{c i}\right)}{\ln \frac{\left(T_{h 1-i}-T_{c o}\right)}{\left(T_{h 1-o}-T_{c i}\right)}}
$$

Assuming no heat transfer through the center of the fin, treated as adiabatic, the fin efficiency $\eta_{\mathrm{f}}$ of a fin is: 


$$
\begin{aligned}
\eta_{f} & =\frac{\tanh (x)}{x} \\
x & =h \sqrt{\frac{h \cdot B}{2 t k}}
\end{aligned}
$$

Where, outside $\mathrm{h}=$ fin height, under root $\mathrm{h}=$ heat transfer coefficient, normally B value is taken as 2.25 for average condition.

\section{Results and optimization}

The primary objective of the process of optimization is to obtain the required value of pressure drop while maintaining the least possible size of the heat exchanger. Optimization is performed to calculate the least possible size while maintaining the needed pressure drop. The dimen sions of fins and no. of layers are varied for obtaining the minimum size. Fin thickness is varied from $0.2 \mathrm{~mm}$ to 0.8 $\mathrm{mm}$ for each of the fin frequency from 400 fins $/ \mathrm{m}$ to 1000 fins/m per meter by keeping number of hot 1 and hot 2 helium layers $=9$, cold helium layers $=36$, height fin $\mathrm{h}=7 \mathrm{~mm}$. Moreover assuming width $=0.2 \mathrm{~m}$. From the above Fig. 2, we can conclude the following: 1) Pressure drop of hot 1 , hot 2 , cold stream decreases with decreasing the fin density and decreasing fin thickness also. 2) Length of all the streams increases with decreasing fin density and decreasing fin thickness. 3) Fin efficiency increases with increasing fin thickness and increasing fin density for 400 fins $/ \mathrm{m}$. But for increasing fin density 500, $600 \mathrm{fins} / \mathrm{m}$, fin thickness increase up to $0.5 \mathrm{~mm}$ and then decreases as the fin efficiency expression is a tan hyperbolic function. Tan hyperbolic function's value is maximum up to $0.5 \mathrm{~mm}$ thickness then it decreases, so also the efficiency. Results obtained from optimization are shown in table 1. Results simulations the heat exchangers in the Aspen HYSYS are shown on figure 3 .

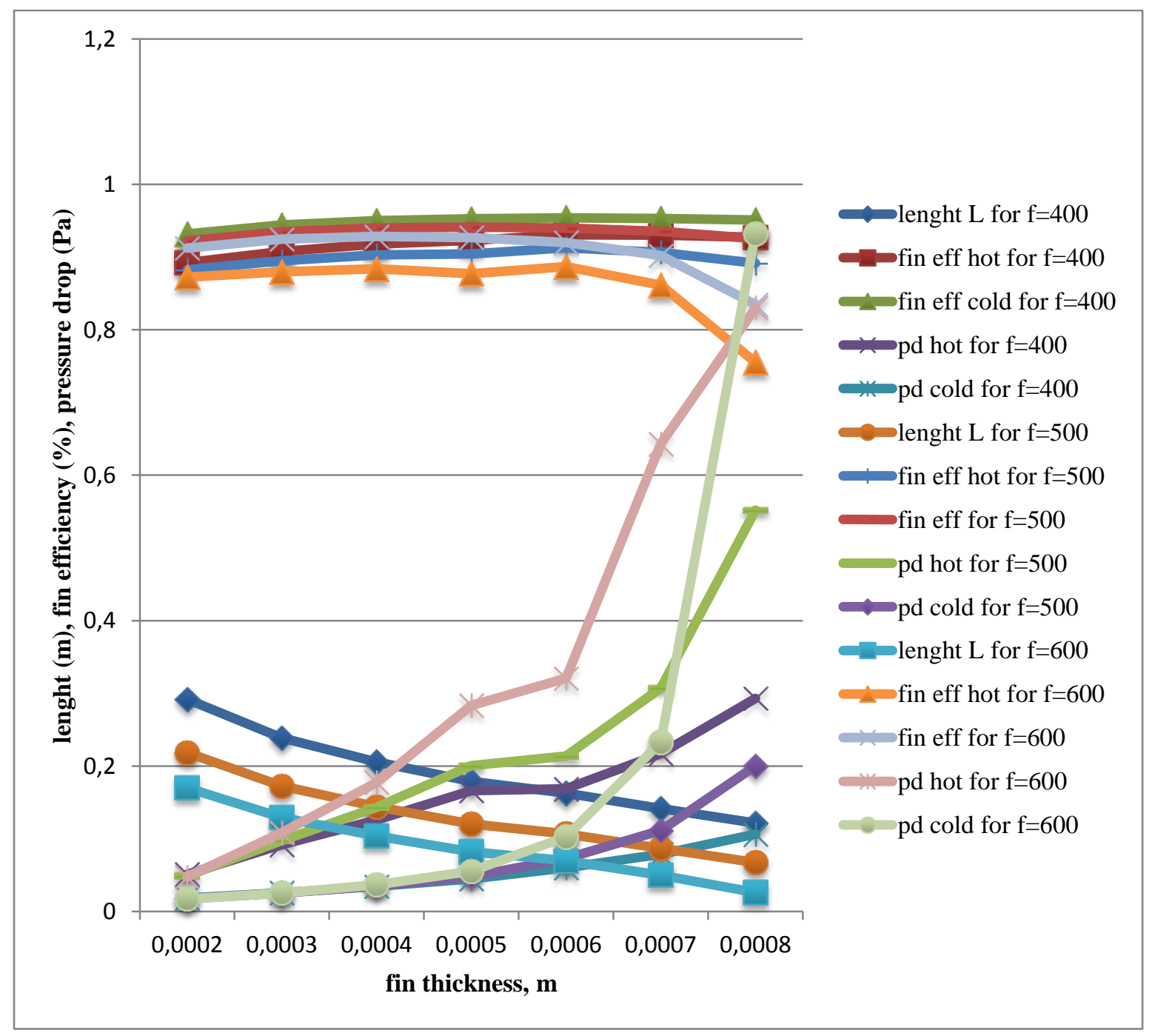

Figure 2 - Changing Fin thickness w.r.t Fin density 
Table 1 - Output of optimization

\begin{tabular}{|c|c|c|}
\hline Parameters & Analytical results & Aspentech software \\
\hline Pressure drop (hot) & $0.470 \mathrm{kPa}$ & $0.459 \mathrm{kPa}$ \\
\hline Pressure drop (cold) & $0,017 \mathrm{MPa}$ & $0.019 \mathrm{MPa}$ \\
\hline No. of layers (N) & 54 & $0,007 \mathrm{~m}$ \\
\hline Fin height (h) & $0,007 \mathrm{~m}$ & $0.0002 \mathrm{~m}$ \\
\hline Fin thickness (t) & $0.0002 \mathrm{~m}$ & $600 \mathrm{fins} / \mathrm{m}$ \\
\hline Fin density (n) & $600 \mathrm{fins} / \mathrm{m}$ & $15000 \mathrm{~W}$ \\
\hline Heat transfer (Q) & $15000 \mathrm{~W}$ & $0.2 \mathrm{~m}$ \\
\hline Length (L) & $0,2 \mathrm{~m}$ & $0.2 \mathrm{~m}$ \\
\hline Width (W) & $0,2 \mathrm{~m}$ & $0.5 \mathrm{~m}$ \\
\hline Height (H) & $0.4 \mathrm{~m}$ & \\
\hline
\end{tabular}

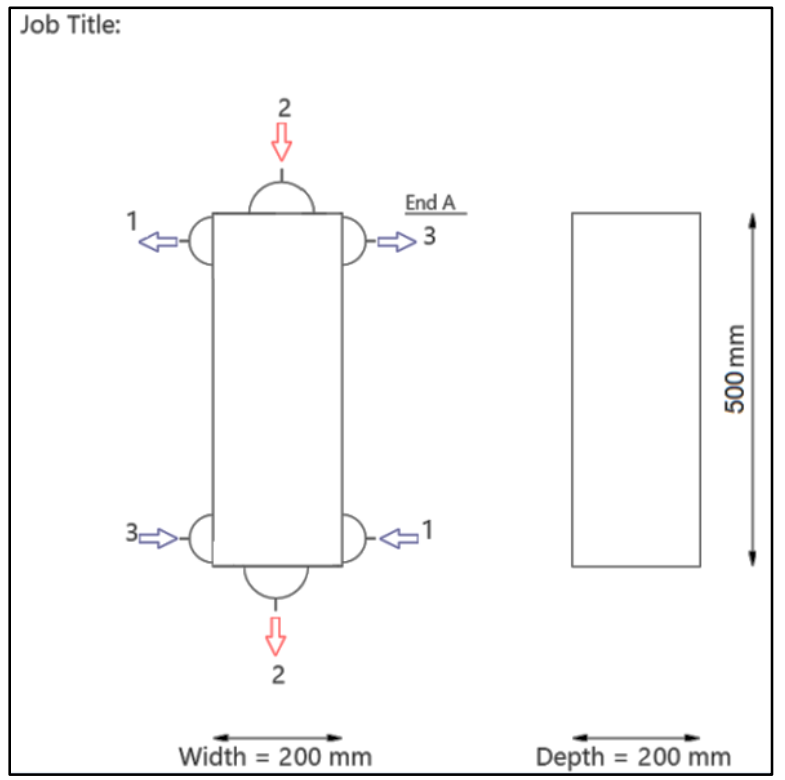

Figure 3 - PFHE from Aspentech results

\section{Conclusions}

A new design optimisation methodology for multistream multi-pass plate-fin exchangers is developed and successfully applied. In the optimisation, the basic fin geometric parameters, such as fin length, width, height and length, and numbers of passes and channels per pass are considered as design variables. By employing the continuous Nusselt number and friction factor expressions, varied heat transfer coefficient and pressure drop can be completed simultaneously with pressure drop consideration. The discrete flow arrangement selection problem can be overcome by using enumeration and comparing the total capital cost of heat exchanger. Eventually, the multi-stream multipass plate-fin heat exchanger design optimisation problem can be converted to a semi-continuous problem, which can be solved efficiently.

The design of plate-fin heat exchanger is done in the excel sheet followed by analysis and optimization by plotting graphs to get lower values of volume, pressure drop and maximum thermal efficiency. AL 3003 is used for analysis, because of its low density, high thermal conductivity and high strength, ductility at low temperature. Serrated fins are used because pressure drop is estimated within the allowed value and also reduced size is achieved. Finally, the overall dimension of the heat exchanger is given as follows: $\mathrm{L}=0.2 \mathrm{~m} \mathrm{H}=0.5 \mathrm{~m} \mathrm{~W}=0.2 \mathrm{~m}$.

\section{References}

1. Taran, V. N. (2004). Proektirovanie apparatov kriogennyh ustanovok. Konspekt lektsiy. Odessa. (in Russian)

2. Mukesh Goya Anindya Chakravarty M.D. Atrey (2014). Two dimensional model for multistream plate fin heat exchangers. Cryogenics, 61, 70-78, doi: https://doi.org/10.1016/j.cryogenics.2014.02.017 